\title{
MANAJEMEN REPRODUKSI DAN PAKAN UNTUK TUJUAN PEMBIBITAN DAN PENGGEMUKAN SAPI BALI DI DESA ALEBO KECAMATAN KONDA KABUPATEN KONAWE SELATAN
}

\author{
Takdir Saili', Hasanudin Bua², Astriana Napirah ${ }^{3}$, Rusli Badaruddin ${ }^{4}$, Syamsuddin $^{5}$, \\ Wa Laily Salido ${ }^{6}$ \\ 1,3,4,5,6 Fakultas Peternakan Universitas Halu Oleo, Kendari \\ ${ }^{2}$ Fakultas Ekonomi dan Bisnis, Universitas Halu Oleo, Kendari \\ email takdir69@yahoo.com
}

\begin{abstract}
ABSTRAK
Kecamatan Konda secara geografis terletak di bagian timur Ibu Kota Kabupaten Konawe Selatan dan merupakan wilayah potensial sentral pengembangan komoditas pertanian dan peternakan. Jarak tempuh Kecamatan Konda dari Ibu Kota Kabupaten $\pm 70 \mathrm{~km}$, dan berjarak sekitar $15 \mathrm{~km}$ dari Kota Kendari yang merupakan Ibu Kota Provinsi Sulawesi Tenggara. Jumlah ternak sapi di Kecamatan Konda pada tahun 2017 sebanyak 5.577 ekor atau $8.23 \%$ dari total populasi yang ada di Kabupaten Konawe Selatan. Salah satu desa yang terdapat di Kecamatan Konda dengan populasi ternak sapi yang banyak adalah Desa Alebo. Populasi sapi di Desa Alebo menempati posisi ke dua (569 ekor) setelah Desa Lambusa (681 ekor). Topografi Desa Alebo tergolong rata, dengan ketinggian tempat sekitar $25 \mathrm{mdpl}$. Sebagian besar masyarakat Desa Alebo mempunyai mata pencaharian sebagai petani dan beternak sapi. Seiring dengan perkembangan waktu, para petani ternak di Desa Alebo sepakat untuk membentuk kelompok tani ternak agar mendapatkan kemudahan di dalam mengakses bantuan permodalan dan sarana produksi serta pemasaran. KKN-TEMATIK ini bertujuan untuk memberikan wawasan dan pengetahuan tentang manajemen pemeliharaan ternak sapi serta pengolahan hasil ikutannya kepada peternak. Metode yang digunakan merupakan metode partisipasi persuasif melalui kegiatan penyuluhan dan praktek secara langsung. Hasil yang telah dicapai pada kegiatan KKN-TEMATIK ini, yaitu adanya peningkatan pengetahuan dan pemahaman peternak maupun petani dalam mengembangkan keberlanjutan usahanya dengan memanfaatkan hijauan pakan ternak berupa rumput unggul (Odot, Benggala dan Setaria) dan limbah pertanian (jerami padi), serta pengolahan limbah kotoran ternak menjadi pupuk kompos dan limbah buah jeruk menjadi pupuk cair. Selain itu pula, telah terjadi peningkatan pendapatan yang diperoleh peternak dari hasil penjualan pupuk kompos dan pupuk cair.
\end{abstract}

Kata Kunci: ternak sapi, pakan ternak, pupuk kompos, pupuk cair.

\begin{abstract}
Konda subdistrict is geographically located in the eastern part of the capital city South Konawe regency and is a potential central area for agricultural and livestock commodity development of agriculture and animal husbandry commodity. The distance of Konda district from the capital of the regency is about $\pm 70 \mathrm{~km}$, and is about $15 \mathrm{~km}$ from Kendari city which is the capital of South East Sulawesi Province. The number of cattle in Konda district in 2017 was 5.577 or $8.23 \%$ of total population in South Konawe regency. One of the village in Konda district that has a large cattle population is Alebo village. The population of cattle in Alebo village
\end{abstract}


occupies the second position (569 head) after Lambusa Village (681 head). The topography of Alebo village is relatively flat, with a height of about $25 \mathrm{~m}$ above sea level. Most of the people in Alebo village have livelihood as farmers and raise cattle. Over time, the livestock farmers in Alebo agreed to form a livestock farmer group in order to get easy access to capital assistance, production tools and marketing facilities. KKN-TEMATIK aims to provide breeders with insights and knowledge about the management of cattle raising and its by-product processing. The method used is a persuasive participatory method through direct counseling and practice. The result of KKN-TEMATIK is the increasing of knowledge and understanding of breeders and farmers in developing business sustainability by utilizing forage in the form of superior grass (Odot, Benggala dan Setaria) and agricultural waste product (paddy straw), also the processing of cattle waste become compost, and orange fruit waste becomes liquid organic fertilizer. In addition, there has been an icrease in income earned by farmers from the sale of compost and liquid organic fertilizer.

Keywords: cattle, feed, compost, liquid organic fertilizer.

\section{PENDAHULUAN}

Paradigma strategi pembangunan peternakan saat ini diorientasikan pada pembangunan wilayah berdasarkan komoditas ternak unggulan, pengembangan kelembagaan petani-peternak, peningkatan usaha dan industri peternakan, optimalisasi pemanfaatan, pengamanan dan perlindungan sumberdaya alam lokal, pengembangan kemitraan yang lebih luas dan menguntungkan serta pengembangan teknologi tepat guna serta ramah lingkungan.

Provinsi Sulawesi Tenggara yang terdiri atas 17 kabupaten dan kota mempunyai luas wilayah $38.140 \mathrm{~km}^{2}$ atau 3.814.000 ha. Wilayah yang luas ini sangat berpotensi untuk pengembangan ternak sapi. Populasi ternak sapi di Sulawesi Tenggara berdasarkan data statistik tahun 2018 adalah 331.958 ekor dan 20.29\% atau 67.746 ekor diantaranya terdapat di Kabupaten Konawe Selatan. Daerah potensial pengembangan peternakan sapi di Kabupaten Konawe Selatan, salah satunya adalah Kecamatan Konda yang memiliki populasi ternak sapi tahun 2017 sebanyak 5.577 ekor atau 8.23\% dari total populasi yang ada di Kabupaten Konawe Selatan. Oleh karena itu sangat diperlukan dukungan semua pihak untuk mengembangkan usaha ternak sapi di Kecamatan Konda yang berorientasi bisnis agar meningkatkan pendapatan dan kesejahtraan keluarga peternak (BPS Konawe Selatan, 2018).

Salah satu desa yang terdapat di Kecamatan Konda dengan populasi ternak sapi yang banyak adalah Desa Alebo. Populasi sapi di Desa Alebo menempati posisi ke dua (569 ekor) setelah Desa Lambusa (681 ekor). Desa Alebo memiliki luas wilayah $3.06 \mathrm{~km}^{2}$ atau sebesar 2.30\% dari luas wilayah Kecamatan Konda yaitu sebesar $132.84 \mathrm{~km}^{2}$ dan berjarak $15 \mathrm{~km}$ dari kota Kendari sebagai 
ibu kota Provinsi Sulawesi Tenggara. Keadaan topografi Desa Alebo tergolong rata, dengan ketinggian tempat sekitar 25 mdpl (Kecamatan Konda Dalam Angka, 2018). Sebagian besar masyarakat Desa Alebo mempunyai mata pencaharian sebagai petani palawija dan beternak sapi. Seiring dengan perkembangan waktu, para petani ternak di Desa Alebo sepakat untuk membentuk kelompok tani ternak agar mendapatkan kemudahan di dalam mengakses bantuan permodalan dan sarana produksi serta pemasaran.

Pada usaha pemeliharaan ternak sapi, setiap anggota kelompok memelihara sapi dengan cara semi intensif, yaitu siang hari digembalakan dan malam hari dikandangkan. Beberapa peternak menyiapkan pakan tambahan berupa rumput atau jerami padi di malam hari ketika ternak mereka dikandangkan. Pada sisi reproduksi, ternak betina hanya mempunyai kesempatan kawin pada saat digembalakan di siang hari. Walaupun beberapa anggota kelompok mempunyai ternak jantan, ternak tersebut hanya ditujukan untuk penggemukan yang dapat dijual setiap saat.

Kondisi ketergantungan petani akan pupuk anorganik yang tinggi, sistem manajemen pemeliharaan ternak yang belum baik, pemanfaatan rumput dan hijauan introduksi sebagai pakan ternak yang belum optimal, teknologi pengolahan pakan ternak yang belum ada dan pengolahan limbah menjadi pupuk kandang pada gilirannya akan membuat usaha mereka menjadi kurang efisien, sehingga dibutuhkan terobosan untuk mensubtitusi peran pupuk anorganik dengan pupuk organik dari kotoran ternak dan memperbaiki manajemen pemeliharaan ternak sapi mereka baik yang berkaitan dengan manajemen pemberian pakan maupun reproduksi ternak.

Berdasarkan uraian tersebut maka diperlukan upaya peningkatan pengetahuan dan penguasaan serta percontohan penerapan teknologi dengan upaya pemberdayaan masyarakat peternak melalui program Pengabdian Kepada Masyarakat Terintegrasi Kuliah Kerja Nyata Tematik (KKNTEMATIK) sebagai wujud penyelenggaraan pendidikan, penelitian dan pengabdian masyarakat. Program KKN-TEMATIK merupakan wadah pembelajaran bagi mahasiswa dan wadah untuk pemberdayaan masyarakat. Oleh karena itu tujuan KKN-TEMATIK ini adalah untuk memberikan wawasan dan pengetahuan tentang manajemen pemeliharaan ternak ruminansia serta pengolahan hasil ikutannya kepada peternak.

Output dari kegiatan KKN-TEMATIK oleh Fakultas Peternakan Universitas Halu Oleo diharapkan terjadi peningkatan pendapatan pada usaha peternakan melalui penguasaan dan peningkatan pengetahuan dengan metode transfer ilmu dan penerapan teknologi pada usaha peternakan yang 
diusahakan oleh masyarakat dengan tahapan-tahapan kegiatan yang sistematik sehingga berimplikasi terhadap peningkatan taraf hidup dan kesejahteraan peternak di Kecamatan Konda Kabupaten Konawe Selatan khusus Desa Alebo.

\section{METODE}

Metode yang digunakan pada program KKN-TEMATIK ini adalah metode partisipasi persuasif melalui kegiatan penyuluhan dan praktek secara langsung. Kegiatan yang dilaksanakan melalui tahaptahap yaitu perekrutan mahasiswa, pembekalan mahasiswa dan pelaksanaan program kegiatan. Pelaksanaan kegiatan KKN-TEMATIK terbagi atas 2 divisi yaitu Divisi Peternakan dan Divisi Sosial Kemasyarakatan. Divisi Peternakan mengadakan kegiatan diantaranya penanaman hijauan pakan ternak, peningkatan produksi dan manajemen kesehatan ternak, bimbingan teknis pembuatan pupuk kompos dan pupuk cair organik (POC), dan bimbingan teknis pembuatan amoniasi jerami. Program yang dilaksanakan pada Divisi Sosial Kemasyarakatan antara lain mengadakan kegiatan bakti sosial dan lomba antar RT yang dilaksanakan di Desa Alebo Kecamatan Konda yang bertujuan untuk mempererat tali silaturahmi antar warga.

Metode pelaksanaan penyuluhan peternakan antara lain sebagai berikut :

\section{Pembuatan Pupuk Kompos}

Metode yang digunakan pada kegiatan pembuatan pupuk kompos adalah dengan cara fermentasi menggunakan terpal plastik. Adapun bahan yang dibutuhkan untuk pembuatan kompos yaitu sebagai berikut:

Bahan: (untuk $100 \mathrm{~kg}$ pupuk kompos)

- $\quad$ Kotoran sapi $60 \mathrm{~kg}$

- $\quad$ Dedak $10 \mathrm{~kg}$

- $\quad$ Sisa pakan, daun gamal dan sekam padi $30 \mathrm{~kg}$

- Gula 100 gram dicairkan dengan $100 \mathrm{ml}$ air

- $\quad \mathrm{EM}-4=100 \mathrm{ml}$

- $\quad$ Air secukupnya

Cara membuat pupuk kompos dengan menggunaan aktivator EM-4 yaitu :

- Larutkan EM-4 dan gula dalam air

- Campurkan kotoran sapi, sisa pakan, daun gamal dan sekam padi secara merata. 
- Siramkan EM-4 secara perlahan-lahan ke dalam campuran kotoran sapi dengan bahan lainnya hingga merata sampai kandungan air mencapai 30\%. Tandanya, bila campuran bahan tersebut dikepal maka air tidak akan menetes dan bila kepalan tangan dilepas maka campuran bahan tersebut tidak menjadi pecah.

- Campuran bahan tersebut digundukkan di atas ubin yang kering dengan ketinggian minimal 15-20 cm dan selanjutnya ditutup dengan terpal selama 14 hari.

- Pertahankan suhu gundukan campuran kotoran sapi dan bahan lainnya maksimal $50^{\circ} \mathrm{C}$. Bila suhunya lebih dari $50^{\circ} \mathrm{C}$ turunkan suhunya dengan membolak-baliknya. Setelah dibalik, tutup kembali dengan terpal.

- Pengecekan suhu dilakukan 2 kali dalam sehari.

- Setelah 14 hari pupuk kompos telah terfermentasi dan siap digunakan sebagai pupuk organik.

\section{Pembuatan Pupuk Organik Cair (POC)}

Adapun alat dan bahan yang digunakan dalam pembuatan pupuk organik cair ini adalah:

- Jerigen

- ember

- Saringan

- Limbah buah jeruk $10 \mathrm{~kg}$

- Air kelapa sebanyak 5 liter

- Air cucian beras sebanyak 2,5 liter

- Gula merah sebanyak $1 / 2$ liter

- Air sebanyak 10 liter.

Cara pembuatan pupuk cair dari limbah jeruk:

- Menghancurkan limbah buah jeruk yang telah disediakan lalu menyaring kemudian dimasukan ke dalam ember.

- Larutkan air di dalam ember, tambahkan pula di dalamnya air kelapa, air beras, dan juga gula merah.

- Aduk semua bahan tersebut hingga tercampur rata.

- Masukan ke dalam jerigen kemudian di tutup rapat dan didiamkan selama 12-15 hari 
agar proses fermentasi dapat berjalan dengan lancar.

- $\quad$ Selepas 12-15 hari pupuk cair tersebut sudah dapat digunakan.

\section{Pembuatan Jerami Amoniasi}

Bahan dan alat yang digunakan dalam proses pembuatan jerami amoniasi yaitu jerami padi, urea, air, wadah plastik, lakban, timbangan, alat pemotong jerami, ember dan alat penyiram. Proses pembuatan jerami amoniasi diawali dengan melarutkan urea ke dalam air, kemudian urea yang telah dilarutkan di dalam air tersebut disiramkan ke jerami yang telah disediakan, dan dicampur sehingga merata. Selanjutnya, jerami dimasukan ke dalam wadah plastik dan ditutup rapat sehingga tidak ada udara yang masuk. Jerami fermentasi disimpan di dalam ruangan agar terhindar dari panas dan hujan selama 21 hari.

Untuk lebih jelasnya tahapan pelaksanaan kegiatan KKN-TEMATIK Fakultas Peternakan Universitas Halu Oleo di Desa Alebo, Kecamatan Konda, Kabupaten Konawe Selatan, Provinsi Sulawesi Tenggara dapat dilihat pada Gambar 1.

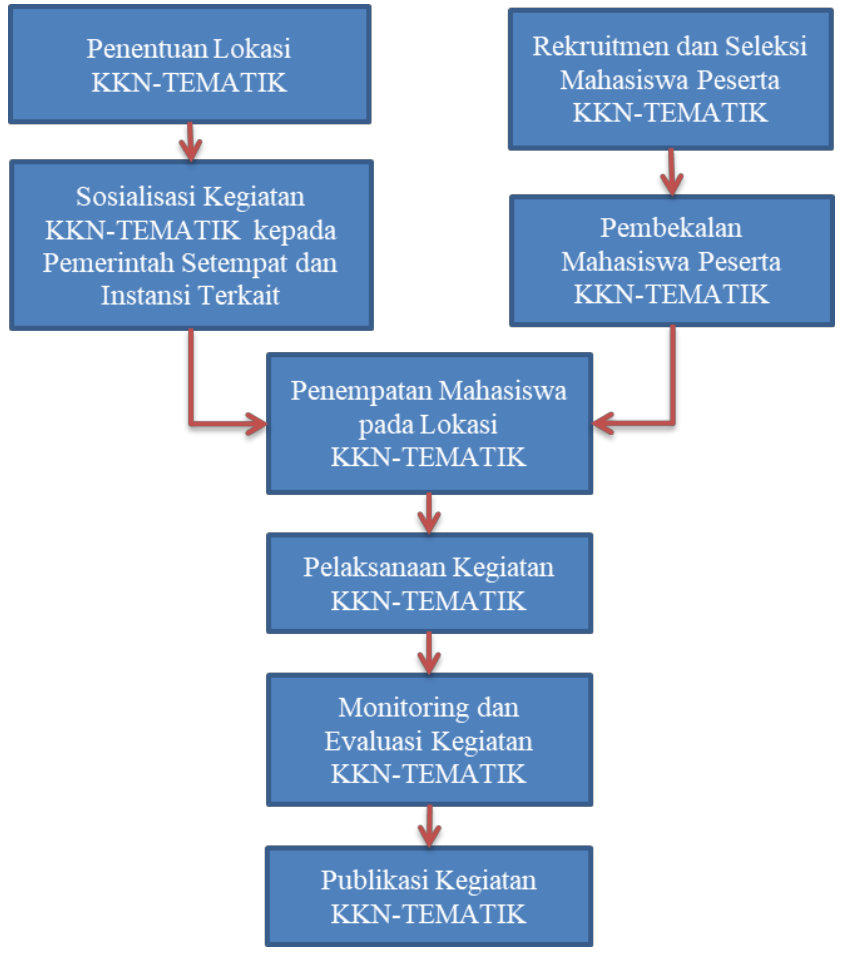

Gambar 1. Tahapan Pelaksanaan Kegiatan KKN-TEMATIK Fakultas Peternakan Universitas Halu Oleo di Desa Alebo, Kecamatan Konda, Kabupaten Konawe Selatan, Provinsi Sulawesi Tenggara, 2019 


\section{Pelaksanaan Kegiatan}

Program KKN-TEMATIK ini dilaksanakan di Desa Alebo, Kecamatan Konda Kabupaten Konawe Selatan, Provinsi Sulawesi Tenggara selama 1 (satu) bulan yaitu dimulai pada tanggal 24 Juli 2019 dan berakhir pada tanggal 24 Agustus 2019.

Metode kegiatan yang diterapkan pada KKN-TEMATIK ini adalah metode aksi yang bersifat partisipati dengan melibatkan masyarakat, aparat pemerintahan desa dan instansi teknis terkait. Bentuk kegiatan pada Program KKN-TEMATIK ini terbagi atas dua bidang/divisi yaitu Divisi Peternakan dan Divisi Sosial Kemasyarakatan.

Program kerja yang dilaksanakan oleh Divisi Peternakan terdiri atas:

1. Pembuatan demplot/percontohan kebun hijauan pakan ternak (HPT)

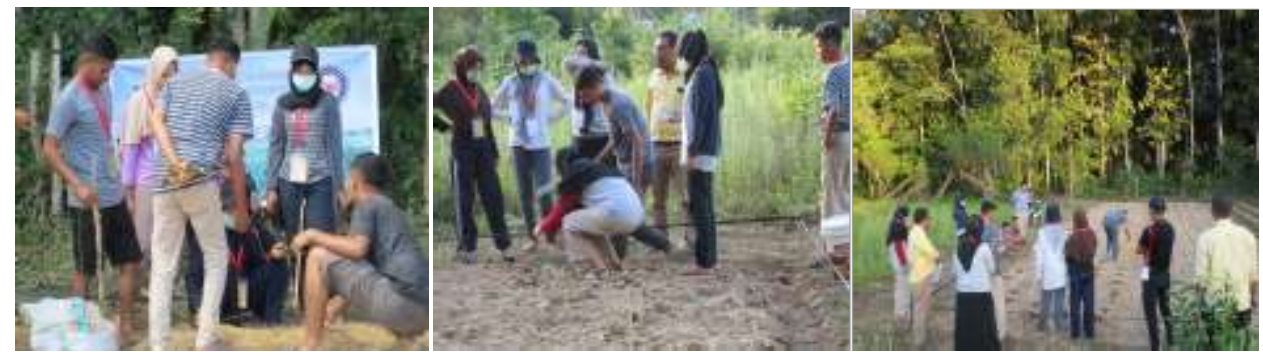

Gambar 2. Demplot penanaman HPT (rumput odot, benggala dan rumput setaria)

2. Pelatihan dan praktek pembuatan pupuk kompos berbahan dasar limbah ternak sapi
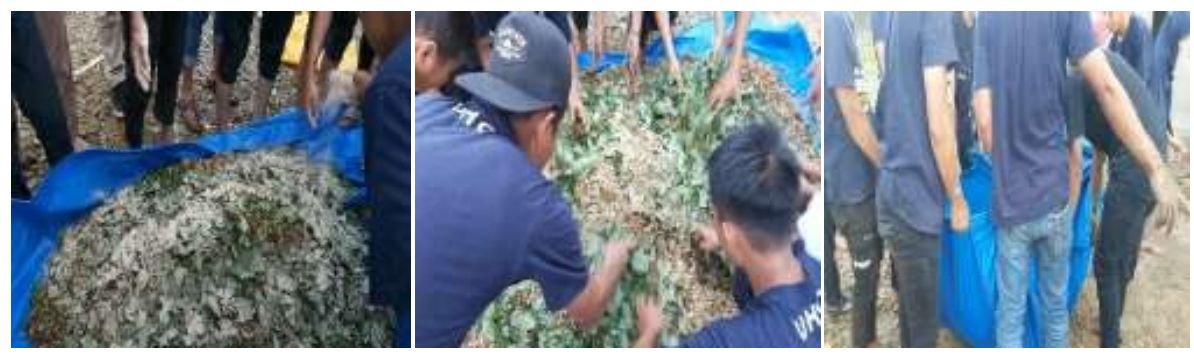

Gambar 3. Pembuatan pupuk kompos

3. Pelatihan dam praktek pembuatan pupuk cair berbahan dasar limbah jeruk

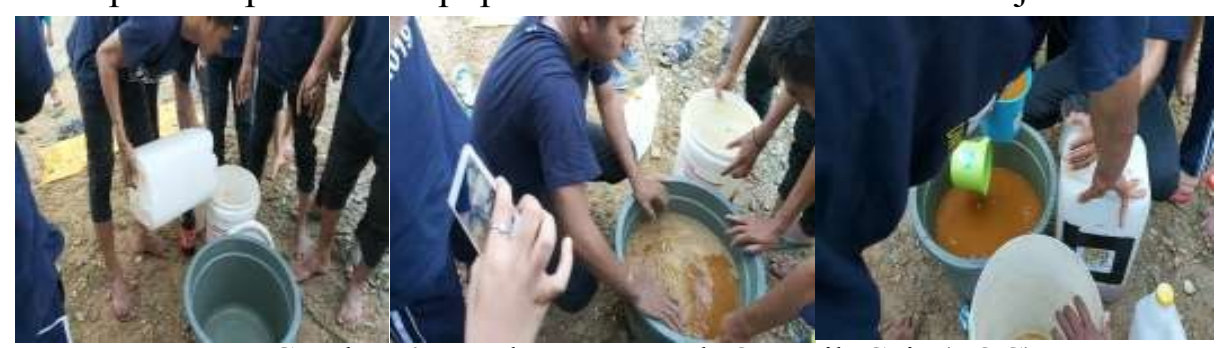

Gambar 4. Pembuatan Pupuk Organik Cair (POC) 
4. Pelatihan dan praktek pembuatan pakan amoniasi jerami;

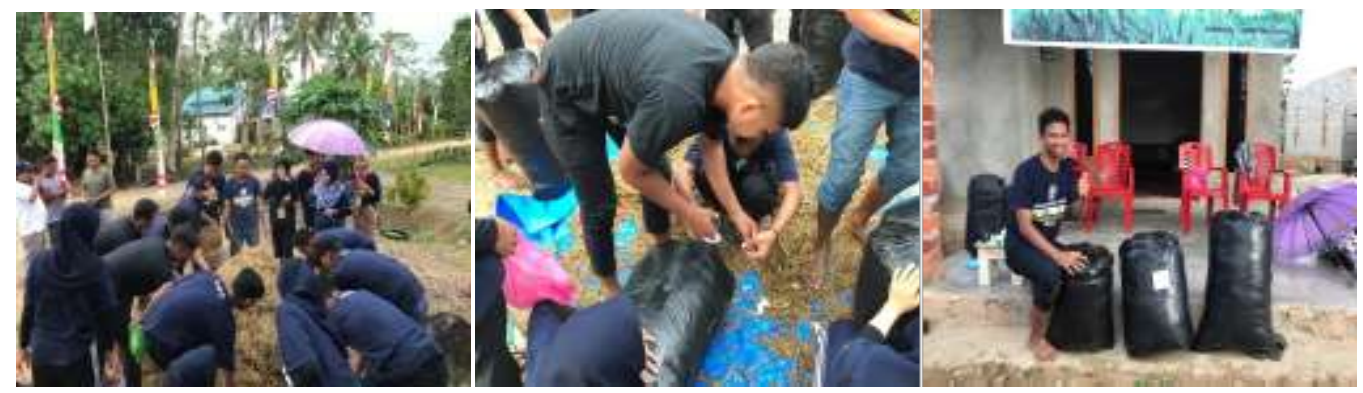

Gambar 5. Praktek pembuatan pakan amoniasi jerami

5. Pelayanan kesehatan ternak

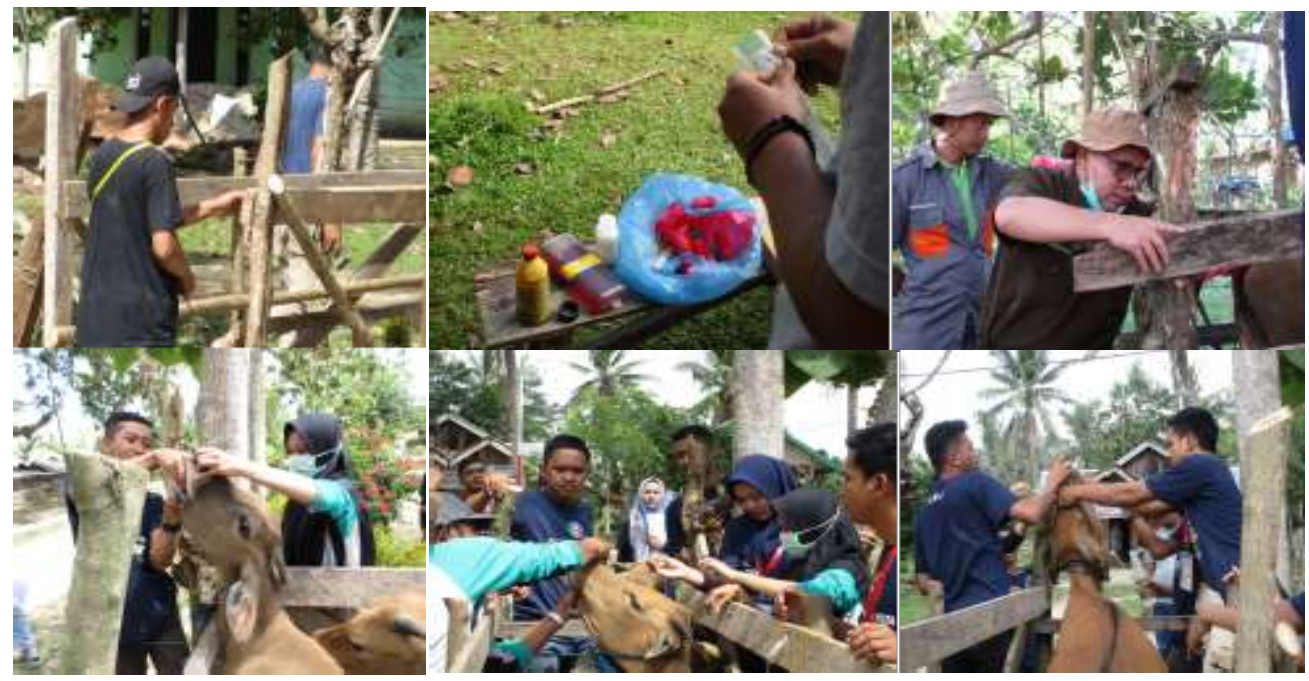

Gambar 6. Pelayanan Kesehatan Ternak

Program kerja yang dilaksanakan oleh Divisi Sosial Kemasyarakatan meliputi kegiatan bakti sosial bersama aparat dan masyarakan desa setempat (Gambar 7) serta kegiatan lomba olahraga se Desa Alebo (Gambar 8).

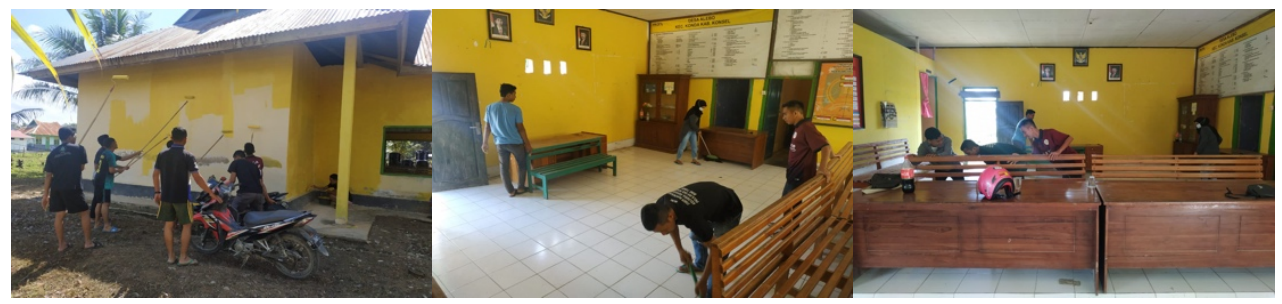

Gambar 7. Kegiatan Bakti Sosial Membenahi Kantor Sesa Alebo 


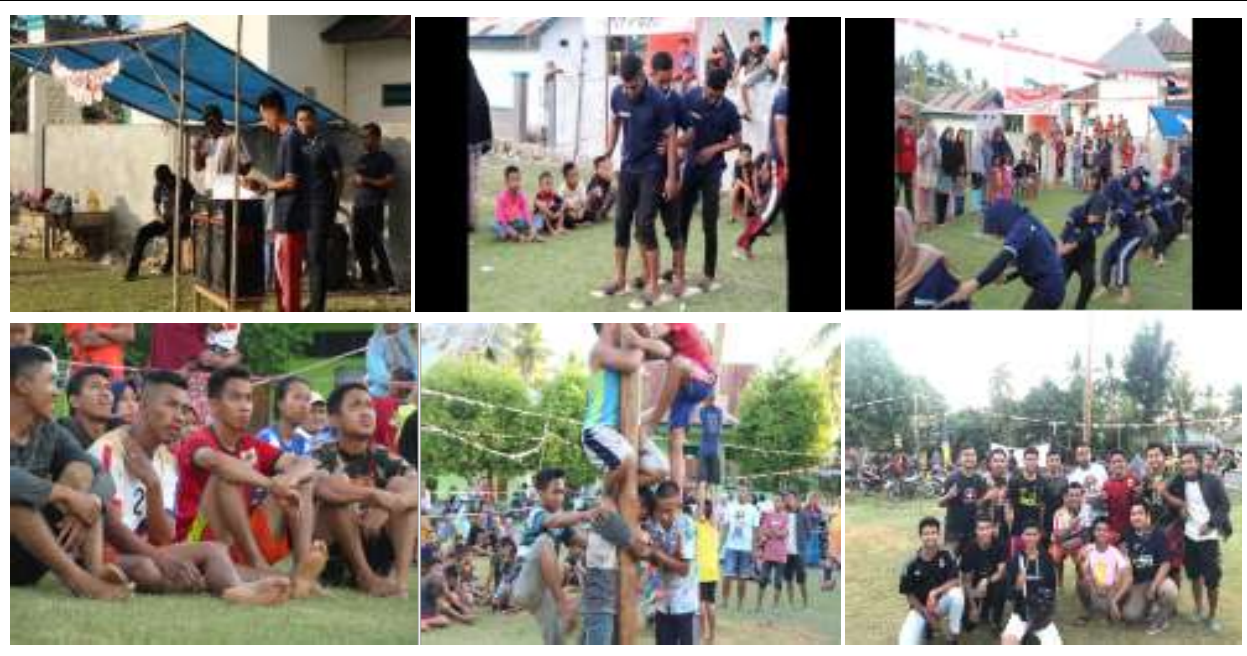

Gambar 8. Kegiatan Lomba Olah Raga se-Desa Alebo.

\section{PEMBAHASAN}

Program KKN-TEMATIK ini adalah kegiatan pengabdian dosen Fakultas Peternakan Universitas Halu Oleo yang terintegrasi dengan kegiatan KKN mahasiswa. Penerapan Program KKNTEMATIK ini di lokasi mitra diawali dengan pertemuan dengan Pemerintah Desa Alebo, selanjutnya pengenalan lokasi/wilayah kegiatan, sosialisasi dan pelaksanaan kegiatan ke kelompok mitra dan masyarakat setempat.

Program kerja yang dilaksanakan oleh Divisi Peternakan dan Divisi Sosial Kemasyarakatan meliputi:

\section{Pembuatan Demplot/Percontohan Kebun Hijauan Pakan Ternak}

Penanaman Hijauan Pakan Ternak (HPT) oleh petani pada umumnya hanya dilakukan dengan memanfaatkan bagian-bagian serta sela-sela tanaman lain pada lahan kebun. Penanaman dengan model tersebut dilakukan oleh peternak dengan maksud dan tujuan guna mengantisipasi jika sewaktu-waktu peternak tidak sempat untuk menggembala dan mencari pakan ternak yang bersumber dari kebun milik warga yang tumbuh secara liar. Menurut Infitria dan Khalil (2014), ketersediaan pakan hijauan merupakan hal yang menjadi prioritas utama dalam memenuhi kebutuhan ternak. Namun, hingga saat ini masyarakat setempat belum melakukan penanaman HPT dengan berbagai potensi yang ada, sementara masih terdapat lahan kosong yang tidak termanfaatkan yang dapat digunakan sebagai media tanam HPT. 
Pembuatan demplot dan penanaman HPT dilakukan pada sebidang tanah/lahan kosong sehingga nilai atau manfaat lahan dapat diperoleh dari produksi HPT tersebut. Hasil survey lokasi, di Desa Alebo masih terdapat lahan kosong dan potensial sebagai media penanaman HPT. Pada kegiatan KKNTEMATIK ini telah ditanam bebepara jenis HPT unggul antara lain, rumput odot, rumput benggala dan rumput setaria. Kegiatan ini diawali dengan pembersihan lahan, pengolahan dan penanaman HPT (Gambar 2). Rumput merupakan hijauan potensial yang memiliki kemampuan adaptasi cukup baik pada berbagai lahan, sehingga diharapkan pada pembuatan demplot dan penanaman HPT ini dapat menjadi wadah bagi masyarakat setempat untuk pengembangan HPT pada masa mendatang untuk memenuhi kebutuhan pakan ternak sapi di Desa Alebo.

\section{Penyuluhan, Pelatihan dan Praktek Pembuatan Pupuk Kompos Berbahan Dasar Limbah Ternak Sapi}

Kompos merupakan salah satu pupuk organik yang digunakan pada pertanian untuk mengurangi pupuk anorganik (Elpawati et.al., 2015). Pembuatan pupuk kompos merupakan suatu upaya pemanfaatan limbah peternakan dengan menggunakan mikroorganisme pengurai yang dapat mengurai bahan organik yang dapat meningkatkan kesuburan tanah. Selain itu, pupuk kompos dapat meningkatkan pendapatan peternak karena dapat dijual serta dapat digunakan sendiri. Bahan dasar yang digunakan dalam pembuatan pupuk kompos pada kegiatan ini adalah feses sapi, sisa pakan, sekam padi dan daun gamal. Daun gamal adalah tanaman leguminosa yang banyak dijumpai di lokasi kegiatan KKN TEMATIK yaitu sekitar perkebunan masyarakat yang dijadikan sebagai pagar.

Pembuatan pupuk kompos dilakukan melalui proses pemeraman/fermentasi selama 14 hari. Selama proses pengomposan, dilakukan pembalikan kompos dengan frekuensi 2 kali sehari agar suhu kompos menjadi merata dan stabil sebab suhu yang tinggi dapat mengakibatkan pupuk kompos menjadi rusak karena terjadi proses pembusukan. Setelah dilakukan pemeraman/fermentasi maka dilakukan pengamatan terhadap perubahan kondisi fisik pupuk kompos yang telah difermantasi. Hasil pengomposan menunjukkan ciri-ciri sebagai berikut: 1) feses, sisa pakan dan daun gamal berwarna coklat kehitam-hitaman, 2) pupuk menjadi menjadi lunak dan mudah dihancurkan, 3) suhu tumpukan sudah mendekati suhu awal pengomposan, 4) tidak berbau menyengat dan hasilnya seperti tanah, 5) volume pupuk kompos menyusut hingga setengahnya. 
Pupuk kompos yang telah jadi dikemas dan siap digunakan pada demplot tanaman hijauan pakan ternak yang ditanam oleh mahasiswa KKN-TEMATIK, dan sebagian lagi dibagikan kepada penduduk setempat untuk diaplikasikan pada tanaman hortikultura yang ditanam sehingga berimplikasi terhadap peningkatan hasil produksi dan pendapatan masyarakat setempat. Peningkatan produktivitas tanaman hortikultura dapat dilakukan dengan efisiensi dalam memanfaatkan lahan maupun tenaga kerja, serta menekan biaya pemupukan. Efisiensi pemupukan dapat dilakukan apabila jumlah pemberian pupuk kimia dapat dikurangi namun kesuburan lahan harus tetap terjaga. Hal ini dapat dilakukan antara lain dengan penyediaan bahan organik atau kompos yang dapat diperoleh dengan cara mudah dan murah dari kotoran sapi (Siswati dan Nizar, 2012). Sementara itu menuru Hutabarat (2002) kotoran sapi dapat mengurangi biaya pengadaan pupuk yang sekaligus dapat mengurangi biaya produksi dan juga dapat menjaga kelestarian bahan organik yang pada gilirannya akan meningkatkan pendapatan petani.

\section{Pelatihan dan Praktek Pembuatan Pupuk Cair dari Limbah Jeruk}

Sebagian besar petani di Desa Alebo juga menanam jeruk manis. Pada setiap musim panen jeruk, banyak buah jeruk yang tidak bisa dipasarkan karena rusak atau ukurannya relstif kecil atau kondisi lain sehingga disortir dan dibuang begitu saja sebagai limbah. Di sisi lain, buah jeruk yang tidak dikonsumsi dapat dijadikan sebagai bahan dasar untuk memproduksi pupuk cair organik. Penggunaan pupuk organik cair merupakan salah satu teknologi alternatif untuk mengurangi pemakain pupuk anorganik. Menurut Marjenah (2012), pupuk organik cair memberikan beberapa keuntungan, misalnya pupuk ini dapat digunakan dalam media tanam padat dengan cara menyiramkannya ke akar ataupun disemprotkan ke bagian tubuh tanaman. Perlakuan pemberian pupuk dengan cara penyemprotan pada daun terbukti lebih efektif dibandingakan dengan perlakuan pemberian pupuk melalui penyiraman pada media tanam. Pemanfaatan limbah buah jeruk sebagai pupuk organik cair merupakan hal baru bagi masyarakat. Oleh karena itu, kegiatan ini merupakan salah satu wadah bagi masyarakat untuk meningkatkan wawasan pengetahuan dalam menciptakan produk pertanian organik bebas pestisida.

Cara pembuatan pupuk cair dari limbah buah jeruk cukup mudah dan praktis, memanfaatkan sumber daya yang mudah untuk ditemukan pada lingkungan sekitar. Pembuatan pupuk organik cair menggunakan prinsip fermentasi selama 12-15 pada kondisi anerob untuk menjaga agar proses fermentasi dapat optimal. Aplikasi pupuk cair organik pada tanaman cukup mudah, akan tetapi penggunaannya harus sesuai dengan dosis kebutuhan tanaman. Aplikasi pupuk cair yang tidak sesuai akan memberikan dampak 
buruk pada tanaman, namun bila sesuai pertumbuhan tanaman akan menjadi lebih baik. Menurut Kusumaningtyas et al. (2015), tujuan utama pupuk organik dibuat dalam bentuk cair adalah agar dapat mempermudah tanaman dalam menyerap unsur-unsur hara yang terkandung di dalamnya dibandingkan dengan pupuk yang berbentuk padat. Pelatihan dan praktek pembuatan pupuk organik cair dari limbah buah jeruk oleh mahasiswa KKN TEMATIK di Desa Alebo Kacamatan Konda kabupaten Konawe Selatan dapat dilihat pada Gambar 4.

\section{Pelatihan dan Praktek Pembuatan Pakan Jerami Amoniasi}

Walaupun di Desa Alebo tidak ada lahan yang memproduksi padi sawah, tetapi beberapa peternak sering memberi pakan pada ternak sapinya dengan jerami padi yang diperoleh dari desa tentangganya terutama pada musim kemarau. Namun demikian pemberian jerami padi pada ternak sapi oleh petani di Desa Alebo hanya diberikan begitu saja tanpa adanya upaya untuk meningkatkan nilai nutrisi jerami sebelum diberikan ke ternak sapi. Jerami padi mempunyai kandungan nutrisi yang rendah, tetapi nilai nutrisi jerami padi dapat ditingkatkan melalui proses fermentasi. Kegiatan fermentasi jerami padi dapat mengurangi serat kasar, meningkatkan palatabilitas dan memperlama masa simpan pakan yaitu digunakan pada musim kemarau dimana ketersediaan hijauan pakan ternak sangat terbatas. Menurut Kradiees (2005), amoniasi dapat dilakukan untuk meningkatkan kualitas jerami padi. Selain itu, teknik amoniasi juga cukup murah, praktis dan hasilnya disukai oleh ternak (Bata, 2008). Amoniasi akan meningkatkan kandungan nitrogen dalam pakan dan memecah ikatan lignin dan serat pakan.

Kegiatan pembuatan jerami amoniasi yang dilakukan oleh mahasiswa KKN-TEMATIK menghasilkan pakan jerami amoniasi yang berkualitas baik dengan ciri-ciri yaitu (1) Bau jerami menunjukkan aroma khas; (2) Tekstur dari jerami menjadi lebih lentur dan lunak; (3) Warna jerami menjadi cokelat muda; (4) Tidak terdapat kapang ataupun jamur; dan (5) Jerami tidak mengalami pembusukan ataupun penggumpalan. Proses fermentasi telah mengubah struktur dan tekstur jerami sehingga memiliki tekstur yang lunak yang menunjukkan serat kasar dari jerami berkurang.

Pemanfaatan teknologi amoniasi jerami diharapkan mampu menyediakan pakan berkualitas bagi ternak sapi terutama pada saat musim kemarau dimana ketersediaan sumber pakan hijauan sangat kurang. Dengan demikian intergrasi antara peternakan-pertanian dalam penyedian pakan ternak sapi dapat meningkatkan produksi ternak yang berimplikasi pada peningkatan pendapatan dan kesejahteraan petani dan peternak. 


\section{Pelayanan Kesehatan Ternak}

Manajemen kesehatan ternak merupakan salah satu aspek yang mempengaruhi produktivitas ternak sapi potong. Menurut Williamson dan Payne (1993), pendekatan mendasar yang diperlukan peternak agar tidak rugi secara ekonomi adalah mempertahankan kesehatan dan mencegah penyakit dengan cara tanggap terhadap kondisi kesehatan ternak. Seekor ternak hanya akan dapat mencapai produktivitas optimal jika berada dalam keadaan sehat, serta terhindar dari segala jenis penyakit. Oleh karena itu, kesehatan ternak perlu diperhatikan dengan baik oleh semua pihak terutama oleh para peternak yang sehari-hari dapat memantau kondisi ternaknya. Beberapa jenis penyakit yang sering menyerang ternak sapi potong di Desa Alebo adalah kembung (bloat), cacingan, dan serangan parasit kutu. Selain pencegahan penyakit melalui kontrol sanitasi kandang, perlu dilakukan pemberian suplemen vitamin pada ternak sapi untuk meningkatkan daya tahan tubuh dan mencegah timbulnya penyakit.

Pelayanan kesehatan ternak dilakukan atas kerjasama Tim KKN-TEMATIK Universitas Halu Oleo dengan Dinas Peternakan Kabupaten Konawe Selatan seperti terlihat pada Gambar 6. Pelayanan kesehatan ternak dihadiri oleh petani setempat yang memiliki ternak sapi. Untuk mempermudah pelayanan kesehatan ternak milik peternak maka Tim mahasiswa KKN-TEMATIK bersama peternak membuat kandang jepit. Dengan adanya kandang jepit akan mempermudah proses pemeriksaan kesehatan ternak. Selain itu, kandang jepit juga berperan penting dalam kegiatan perkawinan ternak sapi melalui Inseminasi Buatan (IB), dan pengendalian maupun pengobatan penyakit pada ternak.

\section{Kegiatan Sosial Kemasyarakatan}

Kegiatan divisi sosial kemasyarakatan adalah mengadakan kerja bakti bersama aparat dan masyarakat Desa Alebo. Kerja bakti difokuskan pada pembenahan Kantor Desa Alebo. Pada hari yang sama, juga dilakukan pembersihan lahan di lokasi sekitar Kantor Desa (Gambar 7). Selain itu, divisi sosial kemasyarakatan juga turut berpartisipasi dalam perayaan Hari Kemerdekaan Republik Indonesia ke-74 tahun 2019. Mahasiswa KKN-TEMATIK menyelenggarakan berbagai lomba olahraga antar RT yang dilaksanakan di desa Alebo Kacamatan Konda. Kegiatan ini banyak melibatkan anak-anak dan remaja yang tinggal di Desa Alebo. Beberapa warga menuturkan bahwa mereka belum pernah mengadakan kegiatan seramai ini dalam rangka memperingati hari kemerdekaan pada tahun-tahun sebelumnya. Tujuan dilaksanakan kegiatan ini adalah untuk mempererat tali silaturahmi sesama warga di Desa Alebo dan meningkatkan semangat juang 
dalam meraih prestasi di antara anak-anak. Dengan adanya kegiatan yang jarang dilaksanakan di Desa ini ternyata tanggapan warga sangat mendukung acara ini karena semua warga antusias mengikuti lomba yang diadakan. Adapun kegiatan lomba antar RT yang dilaksanakan di Desa Alebo Kacamatan Konda Kabupaten Konawe Selatan dapat dilihat pada Gambar 8.

\section{SIMPULAN}

Hasil yang telah dicapai pada kegiatan KKN-TEMATIK ini, yaitu adanya peningkatan pengetahuan dan pemahaman peternak maupun petani dalam mengembangkan keberlanjutan usahanya dengan memanfaatkan hijauan pakan ternak berupa hijauan rumput (Odot, Benggala dan Setaria) dan pakan limbah pertanian (jerami padi), serta pemanfaatan limbah kotoran ternak menjadi pupuk kompos dan limbah buah jeruk menjadi pupuk cair. Selain itu pula, telah terjadi peningkatan pendapatan yang diperoleh peternakan dari hasil penjualan pupuk kompos dan pupuk cair.

\section{DAFTAR PUSTAKA}

Bata, M. 2008. Pengaruh Molases pada Amoniasi Jerami Padi Menggunakan Urea Terhadap Kecernaan Bahan Kering dan Bahan Organik In Vitro. Agripet. 8(2):15-20.

BPS, 2018. Konawe Selatan dalam Angka. Badan Pusat Statistik Kabupaten Konawe Selatan.

Elpawati, Stephani D. D. Y. K. S. dan Dasumiati. 2015. Optimalisasi Penggunaan Pupuk Kompos dengan Pemnfaatan Effektifitas Mikroorganism $10\left(\mathrm{EM}_{10}\right)$ pada Produktivitas Tanaman Jagung (Zea maiz L). 8(2):77-87.

Hutabarat, T. S. P. N. 2002. Pendekatan Kawasan dalam Pembangunan Peternakan. Direktorat Jenderal Bina Produksi Peternakan, Departemen Pertanian. Jakarta. 1-13.

Infitria dan Khalil. 2014. Studi Produksi dan Kualitas Hijauan di Lahan Padang Rumput UPT Peternakan Andalas Padang. Buletin Makanan Ternak. 101(1):25-33.

Kraidess, M. S. 2005. Influence of Urea Treatment And Soybean Meal (Urease) Additin on the Utilization of Wheat Sraw by Sheep. J. Anim. Sci. 18(7):957-965.

Kusumaningtyas, R. D., Mohamad S. E. dan Dhini H. 2015. Pembuatan Pupuk Organik Cairr (POC) dari Limbah Industri Bioetanol (Vinasse) Melalui Proses Fermentasi Berbantuan Promoting 
Microbes. Proceeding SNKPK. 1(6):82-87.

Marjenah. 2012. Respon Morfologi Semai Gaharu (Aquilaria Malaccensis Lamk) Terhadap Perbedaan Teknik Pemberian dan Konsentrasi Pupuk Organik Cair. Seminar Nasional Masyarakat Peneliti Kayu Indonesia XV. Fakultas Kehutanan Universitas Hasanuddin Makassar, Indonesia. November 6-7, 2012.

Siswati L. dan R. Nizar. 2012. Model Pertanian Terpadu Tanaman Hortikultura dan Ternak Sapi untuk Meningkatkan Pendapatan Petani. Jurnal Peternakan Indonesia. 14(2):379-384.

Williamson, G. dan Payne W. J. A. 1993. Pengantar Peternakan di Daerah Tropis. Gajah Mada University Press. Yogyakarta. (Diterjemahkan oleh D. Darmaja). 